\title{
Performance characteristics of diesel engine using blends of Jatropha biodiesel
}

\author{
T. Mahmood', Z.A. Khan'1, S. Hassan ${ }^{1}$ and I.A. Chaudhry² \\ 1 Faculty of Mechanical Engineering Department, University of Management and Technology, Lahore, Pakistan \\ Phone: +923070406954; Fax: +924235184789 \\ 2 Faculty of Industrial Engineering Department, University of Management and Technology, Lahore, Pakistan
}

\begin{abstract}
Jatropha is a tropical herb and can be matured in a diverse soil with low to high rainfall. It provides a chunk of the fuel supply in the transportation and energy sectors. Jatropha biodiesel implies a diesel equivalent and consist of methyl esters. It is produced through the transesterification process which is a chemical reaction of jatropha oil with an alcohol in the presence of a catalyst. In the present work, the physical and chemical attributes of jatropha biodiesel were determined. Various blended samples of jatropha biodiesel with mineral diesel were used to run diesel engine to see the variation of the brake power, brake specific fuel consumption and brake thermal efficiency of engine with percentage increase of jatropha biodiesel in the mixture. It was observed that these properties remain unchanged for $5 \%$ and $10 \%$ blend of jatropha biodiesel to mineral diesel and hence its use is quite feasible without any change in engine design. This provides an edge to the countries having surplus lands in low rain areas to generate $10 \%$ of their energy resources for power generation and transport through the cultivation and growth of jatropha plants.
\end{abstract}

ARTICLE HISTORY

Received: $17^{\text {th }}$ Dec 2020

Revised: 21 $1^{\text {st }}$ Mar 2021

Accepted: 18 ${ }^{\text {th }}$ May 2021

\section{KEYWORDS}

Biodiesel; transesterification; Methyl ester of jatropha oil; fuel properties; engine parameters

\section{INTRODUCTION}

The expanding world population is getting industrialized rapidly with time. This results in an increased number of vehicles and sources of power generation. The increasing consumption of oil and decreasing resources demands exploration of alternative fuels depending on economic, technological, and infrastructural issues.

In recent years, many researchers have shown their keen interest in utilizing biodiesel as an alternative fuel in order to reduce dependence on fossil fuels. Experimental study made with biodiesel from waste cooking oil showed that the engine characteristics remains similar to that of diesel and hence it was found suitable for use in diesel engine. It was also observed that the exhaust emissions were reduced but at the expense of decreased thermal efficiency [1]. The study was conducted with pongamia biodiesel obtained from the transesterification pongamia oil that was used to run diesel engine. The blends of pongamia biodiesel with mineral diesel were tested in different proportions for a diesel engine in the experimental study. The results showed comparable characteristics to that with diesel fuel. The exhaust emissions were decreased however thermal efficiency was also decreased [2]. Emission and performance characteristics of 1.9 MultiJet diesel engine was studied using blends of biodiesel from Neem seed and Camelina Sativa. The results showed that $10 \%$ blends of biodiesel presented better brake power and averagely high brake specific fuel consumption compare to that with diesel fuels for different engine speeds [3]. In another experimental study, the blends of dual biodiesels with mineral diesel in different proportions were used to study the performance of diesel engine. These biodiesels were made by the transesterification of pongamia pinnata oil and mustard oil. The study showed that the thermal efficiency was increased but at the cost of enhanced exhaust emissions [4]. Manikara zapito oil after transesterification was blended in different proportions with diesel and used for the experimental study of diesel engine performance. It was observed that blend of 50\% biodiesel with conventional oil showed an increased brake thermal efficiency and reduced fuel consumption but at the expense of increased $\mathrm{CO}_{2}$ emission [5]. The blends in different proportions of biodiesel obtained from the transesterification of soya bean oil with mineral diesel were used to study the diesel engine characteristics. The results showed significant reduction in the exhaust emissions at the cost of slightly increased fuel consumption and reduced brake thermal efficiency compared to that with diesel fuel [6]. Experimental study was conducted to use biodiesel from mustard oil as a backup fuel for diesel engine without any modification. It was observed that using the blends of biodiesel from mustard oil decreases $\mathrm{CO}$ emissions significantly but at the cost of marginal decreases in its thermal efficiency [7]. A review for the use of biodiesel fuels in CI engine concluded that the use of biodiesel results in an increase of NOx emissions but the use of additive with biodiesel decreases the NOx emissions to great extent and increases the thermal efficiency of CI engine [8]. Corn oil blended in different proportion with diesel oil was tested on diesel engine. The brake thermal efficiency as well as specific fuel consumption compared to those with diesel oil were improved without any change in the exhaust emission species [9]. Different blends of biodiesel from canola, safflower and waste vegetable oil mixtures in diesel fuel were used to study the optimum engine performance applying response surface methodology (RSM) in order to maximize the brake thermal efficiency (BTE) and control of exhaust emission in a diesel engine [10]. A study was carried out on diesel engine using diesel with soy-based biodiesel blends to see the effect of alternative fuel 
on combustion, performance and emissions characteristics. It was concluded that blends with low percentages of soybased biodiesel fuel can be used as alternative fuel in diesel engine [11]. An experimental study was conducted to investigate the performance, emissions and combustion characteristics of diesel engine using biodiesel and its blends derived from catalytic pyrolysis of waste cooking oil. It was found that using biodiesel blends in appropriate ratios for suitable engine loads can reduce NOx emission to $50 \%$ without having significant effect on the combustion efficiency of the engine [12].

Using edible oil as alternative fuel as suggested by many researcher is not a not a right approach toward alternative fuels for diesel engine as it will result in the shortage of food for the peoples. So present research emphases on the production of biodiesel by transesterification of non-edible jatropha oil and using its blends with mineral diesel to run diesel engine. It is required to see the variation of the brake power, brake specific fuel consumption and brake thermal efficiency of engine with percentage increase of jatropha biodiesel in the mixture for its usefulness as an alternative fuel.

\section{METHODOLOGY}

\section{Production of Jatropha Biodiesel}

Jatropha biodiesel is a suitable alternative to diesel fuel because it does not contain any sulfur contents, aromatic hydrocarbons, metals or crude oil residues. The use of oxygenated and lubricating biodiesel fuel tends to increase the life of diesel engines and reduces its $\mathrm{CO}$ emission. The spray pattern of the fuel is affected by the high viscosity and low volatility of Jatropha oils. This may result in the choking of injector, incomplete combustion, carbon deposits and sticking of piston ring to the engine cylinder. In the current work, the viscosity of jatropha oil was reduced by the transesterification process in order to overcome these problems. The transesterification process is represented by following chemical process [13]:

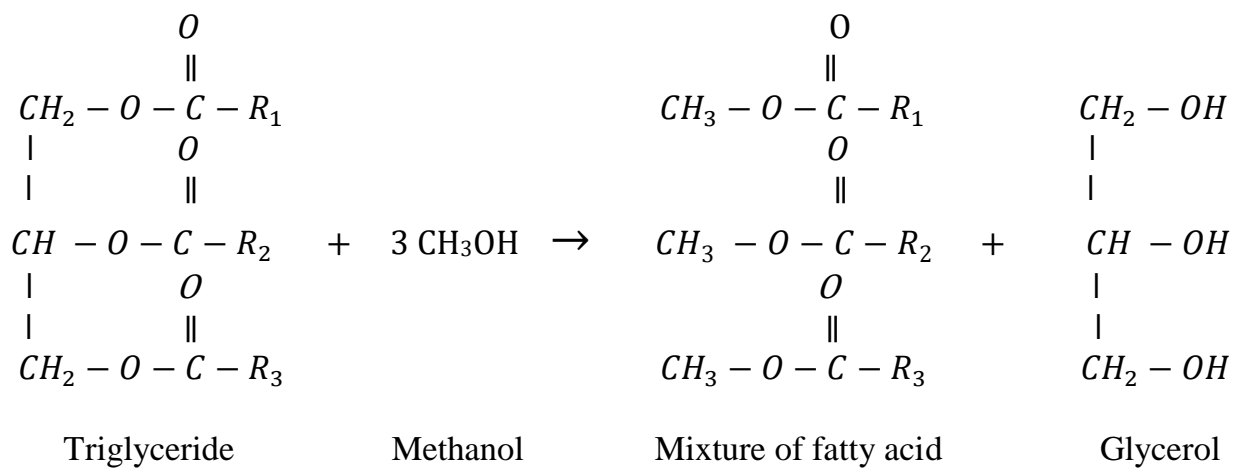

In this reaction one mole of triglyceride reacts with three moles of alcohol to produce mixture of glycerol and fatty esters. The presence of catalyst stimulates the reaction. There are various factors which influence the entire process, including the type of catalyst, time and temperature of reaction and reactants molar ratio. Alcohol to oil molar ratio is one of the most important parameter and determine the efficiency, yield and cost of biodiesel production. In practice the molar ratio should always be greater than stoichiometric ratio, for complete transformation of reaction process [14]. The universally accepted alcohol to oil ratio is between 6:1 and 30:1 [15]. The reactions are categorized as acid catalyzed and base catalyzed and form the basis for the selection of catalyst for the reaction process. The former is slower because of higher temperature requirement, while later is cheaper, less corrosive, faster and requires lower temperature [13]. Temperature affects the rate of reaction and usually the reaction is carried out close to the boiling point of methanol i.e. $60^{\circ} \mathrm{C}$. Further increase in temperature shows negative effect on conversion, and hence mentioning the ample time become important for better results [16]. Transesterification process takes approximately three hours with continuous stirring. Subsequently, the time taken for glycerol to settle down to the bottom after the process is approximately eight hours [17].

\section{Transesterification Process}

The jatropha seeds shown in Figure 1 were purchased from authorized dealers in the market of Southern Punjab in Pakistan and the oil was extracted in the local laboratory using a screw oil press machine. The percentage oil recovery from jatropha seeds was approximately $25 \%$.

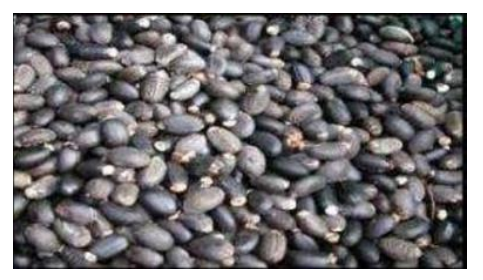

Figure 1. Jatropha seeds 
The samples of jatropha oil, one liter each, were organized. The potassium hydroxide was used as a catalyst with ethanol to oil molar ratio of 6:1. Initially, ethanol and catalyst $(\mathrm{KOH})$ were mixed at elevated temperature. Mixture of $20 \mathrm{~g}$ of potassium hydroxide and 6 liters of ethanol was prepared. Then, the jatropha oil was added at $60{ }^{\circ} \mathrm{C}$ with continuous stirring for 2 hours. The mixture of methyl ester and glycerol was obtained due to the chemical reaction at elevated temperature. The mixture was allowed to settle in a separating funnel by gravity for almost 8 hours. The glycerol settled down at the bottom of the funnel and Jatropha biodiesel was separated as shown in Figure 2.

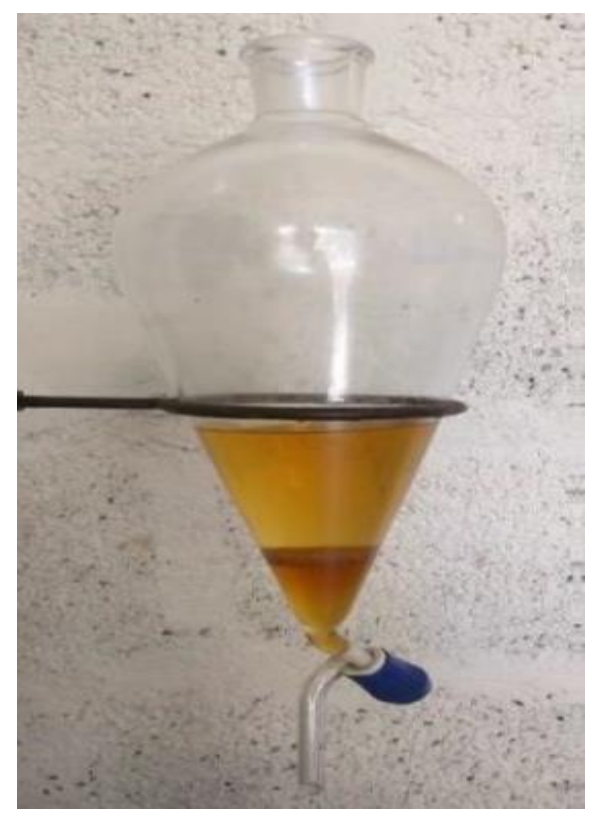

Figure 2. Separating funnel

\section{FUEL PROPERTIES OF JATROPHA BIODIESEL}

Different fuel properties of Jatropha biodiesel are measured and compared to that of mineral diesel and jatropha oil. These properties are density, kinematic viscosity, calorific value and flash point. The evaluation of the properties of jatropha biodiesel and its comparison with mineral diesel and jatropha oil is given in the session that follows next.

\section{Density}

Density is one of the most distinguished criteria of the biodiesel and provides useful information regarding its composition and related performance parameters at a given temperature. Density of jatropha biodiesel after transesterification process was measured and compared with that of diesel and jatropha oil. The results are tabulated in Table 1. It shows that the density of jatropha biodiesel is comparable to that of diesel and hence produce a uniform mixture of the blends of jatropha biodiesel and mineral diesel for injection to diesel engine cylinder.

Table 1. Density of fuels

\begin{tabular}{ccc}
\hline No & Type of fuel & Density $\left(\mathrm{kg} / \mathrm{m}^{3}\right)$ \\
\hline 1 & Mineral diesel & 830 \\
2 & Jatropha oil & 918 \\
3 & Jatropha biodiesel & 870 \\
\hline
\end{tabular}

\section{Kinematic Viscosity}

The higher viscosity of jatropha oil is the major hindrance for its direct use as fuel in diesel engines. The viscosity of jatropha oil was reduced significantly by transesterification process. Viscosity is an important property of fuel and influences the fuel injection at low temperature. It is convenient to obtain refine droplets of oil with its lower viscosity as the fuel pressure decreases with increase in its viscosity. Redwood viscosity value is the time required in seconds for 50 $\mathrm{ml}$ of oil to sneeze out of a viscometer at a fixed temperature [18]. The values of measured viscosity are different for different temperatures. A decrease in viscosity of jatropha oil is observed with an increase in temperature and it is almost 
same to the viscosity of diesel at temperature above $90{ }^{\circ} \mathrm{C}$. The values of kinematic viscosity of jatropha oil and Jatropha biodiesel were determined experimentally at $40^{\circ} \mathrm{C}$ using a kinematic viscosity tester shown in Figure 3.

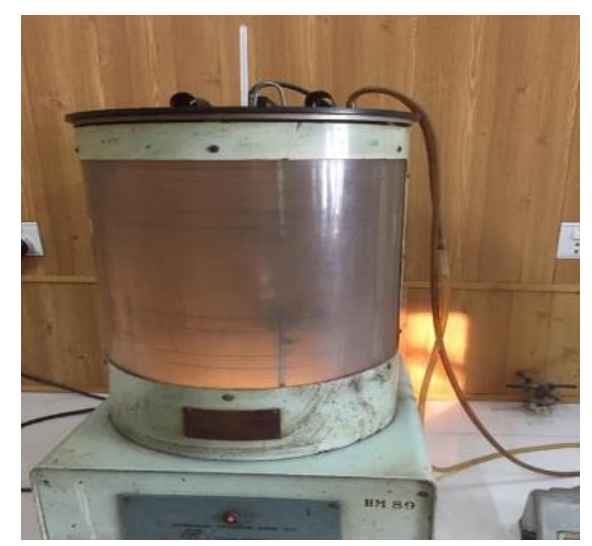

Figure 1. Kinematic viscosity tester

The kinematic viscosity of Jatropha oil and Jatropha Biodiesel are tabulated in Table 2. The comparison shows that there is a significant decreases in the kinematic viscosity of jatropha oil after its transesterification. The average value of Jatropha biodiesel is $3.97 \mathrm{cSt}$ and is comparable with that of EN 590 diesel where the viscosity ranges from $2 \mathrm{cSt}$ to 4.5 cSt.

Table 2. Kinematic viscosity of Jatropha oil and Jatropha biodiesel

\begin{tabular}{|c|c|c|c|c|c|c|c|}
\hline \multirow{3}{*}{ No } & \multirow{3}{*}{$\begin{array}{l}\text { Temperature } \\
\left({ }^{\circ} \mathrm{C}\right)\end{array}$} & \multicolumn{3}{|c|}{ Jatropha Oil } & \multicolumn{3}{|c|}{ Jatropha Biodiesel } \\
\hline & & \multirow{2}{*}{$\begin{array}{l}\text { Efflux time } \\
\text { (s) }\end{array}$} & \multicolumn{2}{|c|}{$\begin{array}{c}\text { Kinematic viscosity } \\
(\mathrm{cSt})\end{array}$} & \multirow[t]{2}{*}{$\begin{array}{l}\text { Efflux time } \\
\qquad(\mathrm{s})\end{array}$} & \multicolumn{2}{|c|}{$\begin{array}{c}\text { Kinematic viscosity } \\
(\mathrm{cSt})\end{array}$} \\
\hline & & & Test values & Average & & Test values & Average \\
\hline 1 & 40 & 5223 & 52.75 & & 387 & 3.9087 & \\
\hline 2 & 40 & 5235 & 52.87 & 52.80 & 395 & 3.985 & 3.97 \\
\hline 3 & 40 & 5227 & 52.79 & & 400 & 4.04 & \\
\hline
\end{tabular}

\section{Calorific Value}

The calorific value of the biodiesel/diesel samples represents the energy content of the fuel. It is an important property in defining the credibility of a fuel as a replacement to diesel. The calorific values of the samples of the diesel, jatropha oil and Jatropha biodiesel were measured using a bomb calorimeter as shown in Figure 4.

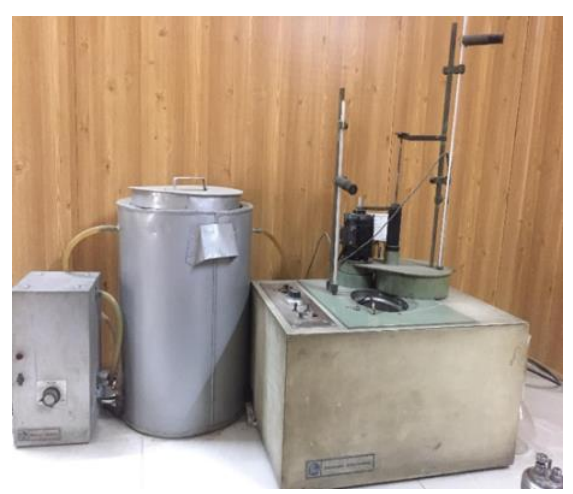

Figure 4. Bomb calorimeter with accessories

The results depicts quite familiar characteristics of jatropha biodiesel to that of diesel. The calorific values of the diesel, jatropha oil and jatropha biodiesel are tabulated in Table 3. 
Table 3. Calorific values of the fuel samples

\begin{tabular}{ccc}
\hline No & Type of fuel & Calorific value $(\mathrm{MJ} / \mathrm{kg})$ \\
\hline 1 & Diesel & 43 \\
2 & Jatropha oil & 39 \\
3 & Jatropha Biodiesel & 38 \\
\hline
\end{tabular}

\section{Flash Point Temperature}

Flash point temperature of jatropha biodiesel is the minimum temperature at which the ignition of biodiesel take place. It has inverse relation with volatility of fuel and is considered as an important property for the secure handling of diesel fuel [18]. The flash point of biodiesel was determined using standard testing method. The flash point temperature values of diesel, Jatropha oil and Jatropha biodiesel are tabulated in Table 4. The results show a significant reduction in the flash point temperature of jatropha oil after transesterification.

Table 4. Flash point Temperature of Diesel and Jatropha oil and Jatrpha biodiesel

\begin{tabular}{ccc}
\hline No & Type of fuel & Temperature $\left({ }^{\circ} \mathrm{C}\right)$ \\
\hline 1 & Diesel oil & $52-96$ \\
2 & Jatropha oil & $210-220$ \\
3 & Jatropha biodiesel & 60 \\
\hline
\end{tabular}

\section{EXPERIMENTAL SETUP AND RESULTS}

After measuring the properties of jatropha biodiesel, experiments were carried out on the single cylinder, four stroke, direct injection, air cooled diesel engine using diesel as the fuel to generate base-line data. Experiments were repeated with the blends of jatropha biodiesel in diesel for a comparison with the base-line data. The experimental setup is shown in Figure 5.

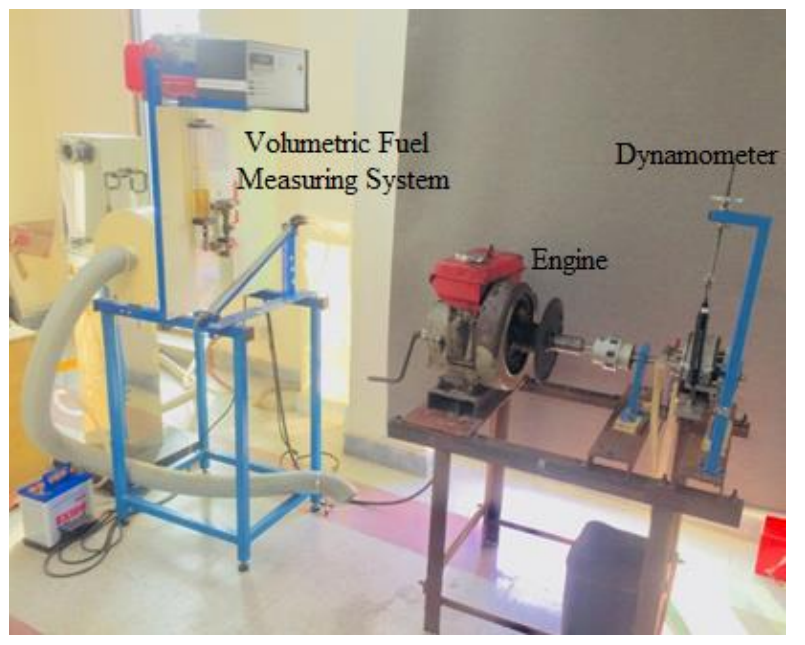

Figure 5. Experimental setup

The engine performance characteristics such as brake power, brake specific fuel consumption and brake thermal efficiency were determined with blended mixture of jatropha biodiesel and diesel. The blends of jatropha biodiesel ranging from 5\% to 50\% were used in various samples. Sample J5D95 represents the blended mixture of 5\% jetropha biodiesel and $95 \%$ diesel. The engine characteristics using the blended mixture of biodiesel and diesel were determined and the performance was compared with that using diesel as fuel. The brake power at engine crankshaft is measured by connecting a power absorption device with engine shaft. The brake power (BP) is determined as:

$$
B P=\frac{2 \pi N T}{60}
$$

Where $\mathrm{N}$ and $\mathrm{T}$ are the measured rpm and torque at the shaft. Different blends of jatropha biodiesel with mineral diesel were used to determine the brake power of engine. These values are listed in Table 5. The values were compared with the 
brake power of the engine running on mineral diesel. The results shows that the use of blended fuels J5D95 and J10D90 results in $2 \%$ to $4 \%$ reduction in the engine brake power compared to that with mineral diesel. Whereas the use of blended fuels J20D80, J30D70 and J40D60 results in 13\% to 18\% reduction in the brake power of the engine. However for J50D50 this reduction is $37 \%$.

Table 5. Brake power of diesel engine using different belnds of jatropha biodiesel with mineral diesel

\begin{tabular}{ccccc}
\hline No & Fuel & $\begin{array}{c}\mathrm{N} \\
(\mathrm{rpm})\end{array}$ & $\begin{array}{c}\mathrm{T} \\
(\mathrm{N} . \mathrm{m})\end{array}$ & $\begin{array}{c}\text { BP } \\
(\mathrm{W})\end{array}$ \\
\hline 1 & Diesel & 3405 & 2.156 & 768.4 \\
2 & J5D95 & 3405 & 2.107 & 751 \\
3 & J10D90 & 3400 & 2.058 & 732 \\
4 & J20D80 & 3415 & 1.862 & 666 \\
5 & J30D70 & 3440 & 1.764 & 635 \\
6 & J40D60 & 3475 & 1.734 & 628 \\
7 & J50D50 & 3493 & 1.452 & 530 \\
\hline
\end{tabular}

The brake specific fuel consumption (BSFC) has inverse relation with the load [5, 19]. BSFC in $\mathrm{kg} . \mathrm{hr} / \mathrm{kW}$ is determined as:

$$
B S F C=\frac{\text { Mass of fuel }(\mathrm{kg} / \mathrm{s}) \times 3600}{B P(\mathrm{~kW})}
$$

BSFC for of engine running on blended fuel with various composition of diesel and jatropha biodiesel were determined and compared with that of mineral diesel. These values ae listed in Table 6.

Table 6. BSFC of engine running on blended fuel with various composition of diesel and jatropha biodiesel

\begin{tabular}{ccccccc}
\hline No & Fuel & $\begin{array}{c}\text { Volume flow rate } \\
(\mathrm{L} / \mathrm{s})\end{array}$ & $\begin{array}{c}\text { Density } \\
(\mathrm{kg} / \mathrm{L})\end{array}$ & $\begin{array}{c}\text { Mass flow rate } \\
(\mathrm{kg} / \mathrm{s})\end{array}$ & $\begin{array}{c}\text { Brake power } \\
(\mathrm{kW})\end{array}$ & $\begin{array}{c}\text { BSFC } \\
(\mathrm{kg} / \mathrm{kW} . \mathrm{h})\end{array}$ \\
\hline 1 & Diesel & 0.00020 & 0.831 & 0.00016 & 0.768 & 0.777 \\
2 & J5D95 & 0.00019 & 0.832 & 0.00016 & 0.751 & 0.7765 \\
3 & J10D90 & 0.00022 & 0.834 & 0.00018 & 0.732 & 0.909 \\
4 & J20D80 & 0.00028 & 0.838 & 0.00024 & 0.666 & 1.310 \\
5 & J30D70 & 0.00037 & 0.842 & 0.00031 & 0.635 & 1.801 \\
6 & J40D60 & 0.00057 & 0.84 & 0.00046 & 0.628 & 2.643 \\
7 & J50D50 & 0.00073 & 0.85 & 0.00062 & 0.530 & 4.212 \\
\hline
\end{tabular}

The results reflect the effect of using blended mixture of jatropha biodiesel and mineral diesel on the brake specific fuel consumption. It shows that using fuels J5D95 and J10D90 results in the increase of 0\% to 13\% in the BSFC. It is also observed that BSFC increases with the percentage increase of Jatropha biodiesel in the mixture. Using the blended fuels J20D80, J30D70, J40D60 and J50D50 shows considerable increase in the brake specific fuel consumption. The variation of the brake specific fuel consumption with brake power for various samples of blended fuel of jatropha biodiesel with mineral diesel is shown in Figure 6. It shows that the fuel consumption increases with the increase of jatropha percentage in the blended fuel.

Brake thermal efficiency (BTE) has direct relation to brake power. It is the ratio of the brake power and energy released $[1,19]$. Different blends of jatropha biodiesel and mineral diesel were used to determine the BTE of engine. These values are listed in Table 7. The values were compared with the BTE of same engine running on mineral diesel. The results reflect the effect of using blended mixture of jatropha biodiesel and mineral diesel on BTE of the engine. The outcomes show that using fuels J5D95 and J10D90 result in the decrease of engine BTE in the range of 0.03\% to $1.44 \%$. It is also observed that BTE decrease with the increase of Jatropha biodiesel in the mixture. The use of blended fuels J20D80, J30D70 and J40D60 results in the reduction in the brake thermal efficiency of the engine from 4.4\% to $7.7 \%$. Whereas for J50D50 this reduction is $8.9 \%$.

The variation of the brake thermal efficiency with brake power for various samples of fuel having blends of Jatropha biodiesel with mineral diesel is shown in Figure 7. The Figure shows that BTE decreases with the increase of jatropha biodiesel in the blended fuel. 


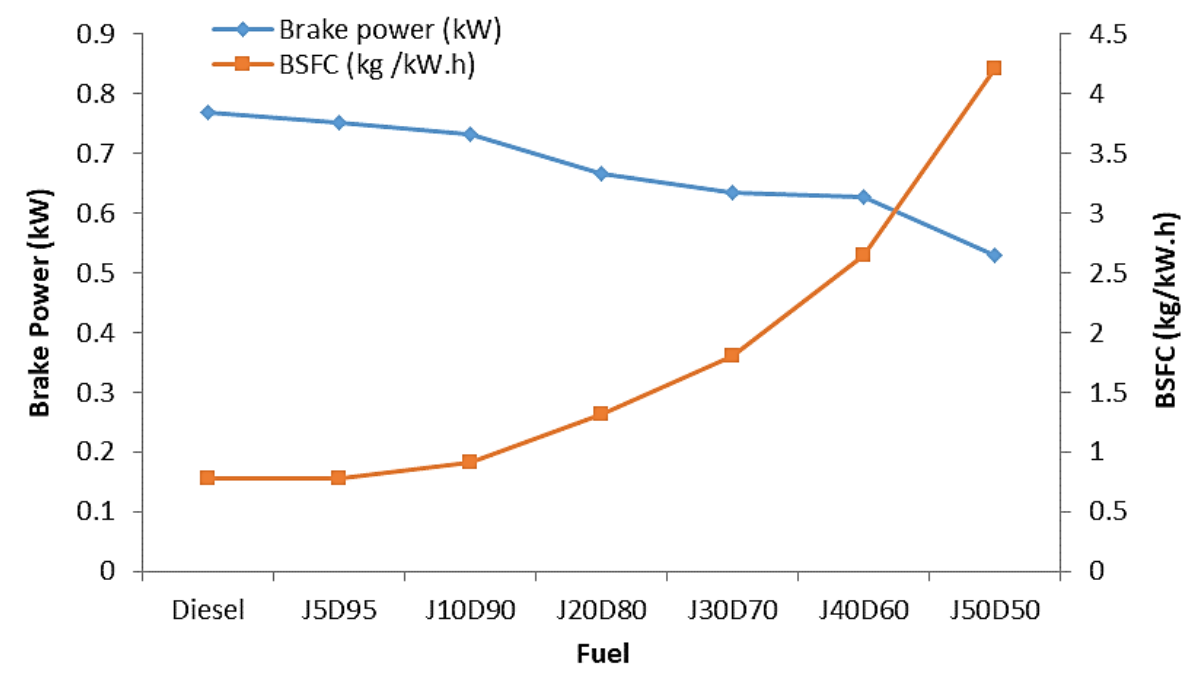

Figure 6. Relationship of brake power and brake specific fuel consumption for various blended mixtures

Table 7. Brake thermal efficiency of engine running on diesel blended with Jatropha biodiesel

\begin{tabular}{cccccc}
\hline No & Fuel & $\begin{array}{c}\text { Mass flow rate } \\
(\mathrm{kg} / \mathrm{s})\end{array}$ & $\begin{array}{c}\text { Calorific values } \\
(\mathrm{kJ} / \mathrm{kg})\end{array}$ & $\begin{array}{c}\text { Brake power } \\
(\text { Watt })\end{array}$ & $\begin{array}{c}\text { Brake thermal } \\
\text { efficiency } \\
\text { Percent }(\%)\end{array}$ \\
\hline 1 & Diesel & 0.000166 & 43000 & 768.4 & 11 \\
2 & J5D95 & 0.00016 & 42750 & 751 & 10.97 \\
3 & J10D90 & 0.00018 & 42500 & 732 & 9.56 \\
4 & J20D80 & 0.00024 & 42000 & 666 & 6.6 \\
5 & J30D70 & $0 . .00031$ & 41500 & 635 & 4.93 \\
6 & J40D60 & 000046 & 41000 & 628 & 3.29 \\
7 & J50D50 & 0.00062 & 40500 & 530 & 2.11 \\
\hline
\end{tabular}

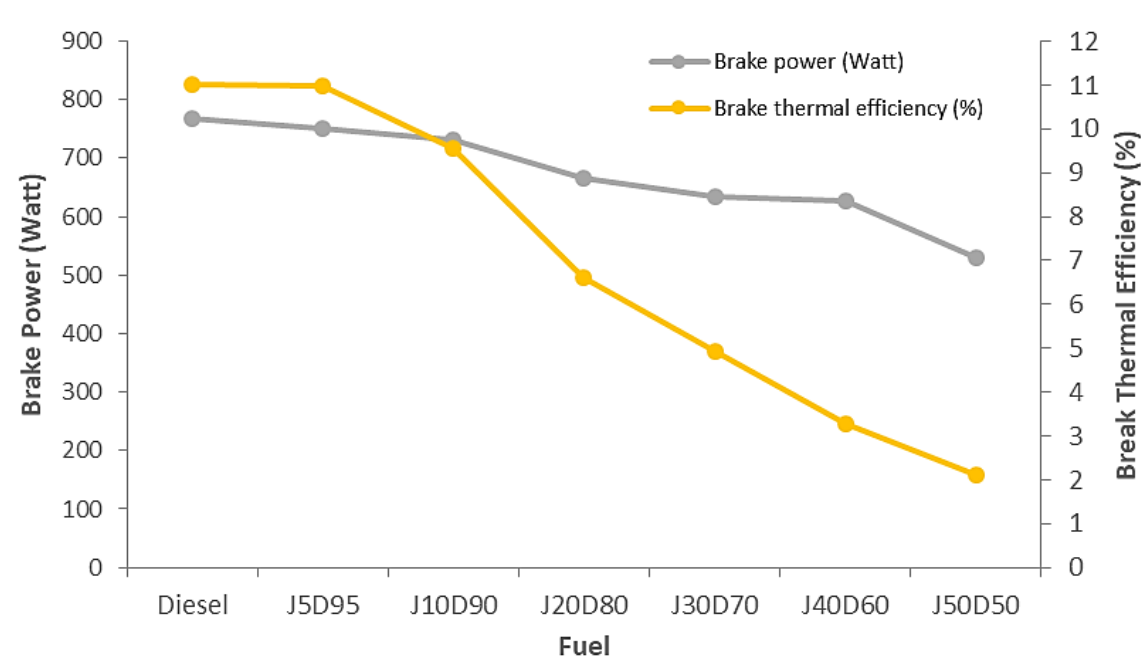

Figure 7. Relationship of brake power and brake thermal efficiency for diesel enging running on blended fuel 


\section{DISCUSSION AND CONCLUSIONS}

The investigations were carried out to find the suitability of jatropha biodiesel as an alternative to mineral diesel. Jatropha biodiesel was produced by the transesterification of jatropha oil and subsequently, its physical and chemical properties were determined. It was observed that there was a significant reduction in the viscosity of jatropha biodiesel obtained from the transesterification process of jatropha oil. This enables the direct usage of jatropha biodiesel in diesel engine without any engine modification. The calorific value, flash point temperature and density of jatropha biodiesel were found comparable to those of mineral diesel. It is concluded that jatropha biodiesel can be used in blends with mineral diesel without any modification in the engine design.

The experiments were carried out on the diesel engine using blends of jatropha biodiesel with mineral diesel and its performance characteristics were determined. These characteristics were compared with the engine characteristics using mineral diesel. The results shows that the use of blended fuels J5D95 and J10D90 results in 2\% to 4\% reduction in the engine brake power compared to that with diesel oil. Whereas the use of blended fuels J20D80, J30D70 and J40D60 results in $13 \%$ to $18 \%$ reduction in the brake power of the engine. However for J50D50 this reduction is $37 \%$. Subsequently, the experiments were carried out to observe the effect of using blended mixture of jatropha biodiesel and mineral diesel on BSFC. The outcomes show that using fuels J5D95 and J10D90 result in the increase of brake specific fuel consumption from $0.05 \%$ to $13 \%$. It is also observed that BSFC increases with the percentage increase of Jatropha biodiesel in the mixture. Using the blended fuels J20D80, J30D70, J40D60 and J50D50 shows considerable increase in the brake specific fuel consumption. The experiments were also carried out to observe the effect of using blended mixture of jatropha biodiesel and mineral diesel on BTE of the engine. The outcomes show that using fuels J5D95 and J10D90 result in the negligible decrease of BTE of the engine and fall in the range of $0.03 \%$ to $1.44 \%$. It is also observed that BTE decrease with the percentage increase of jatropha biodiesel in the mixture. The use of blended fuels J20D80, J30D70 and J40D60 results in 4.4\% to $7.7 \%$ reduction in the brake power of the engine. Whereas for J50D50 this reduction is $8.9 \%$.

Therefore, it is concluded that J10D90 with 10\% jatropha biodiesel and 90\% mineral diesel blends is the most appropriate combination of biodiesel fuel with mineral diesel for optimum engine performance. The brake power, brake specific fuel consumption and brake thermal efficiency of the engine running on J10D90 fuel are very close to engine characteristics running on mineral diesel. This provides an edge to the countries having surplus lands in low rain areas to generate 10\% of their energy resources for power generation and transport through the cultivation and growth of jatropha plants for the yield of jatropha seeds used in the extraction of jatropha oil. Hence, the countries having lands with low rain can generate $10 \%$ of their energy resources for power generation and transport through the growth of plants for the yield of jatropha.

\section{REFERENCES}

[1] K. Nantha Gopal, A. Pal, S. Sharma, C. Samanchi, K. Sathyanarayanan, and T. Elango, "Investigation of emissions and combustion characteristics of a CI engine fueled with waste cooking oil methyl ester and diesel blends," Alexandria Engineering Journal, vol. 53, pp. 281-287, 2014.

[2] K. Nantha Gopal and R. Thundil Karupparaj, "Effect of pongamia biodiesel on emission and combustion characteristics of DI compression ignition engine," Ain Shams Engineering Journal, vol. 6, pp. 297-305, 2015.

[3] B. A. Oni and D. Oluwatosin, "Emission characteristics and performance of neem seed (Azadirachta indica) and Camelina (Camelina sativa) based biodiesel in diesel engine," Renewable Energy, vol. 149, pp. 725-734, 2020.

[4] K. Srithar, K. Arun Balasubramanian, V. Pavendan, and B. Ashok Kumar, "Experimental investigations on mixing of two biodiesels blended with diesel as alternative fuel for diesel engines," Journal of King Saud University - Engineering Sciences, vol. 29, pp. 50-56, 2017.

[5] R. Sathish Kumar, K. Sureshkumar, and R. Velraj, "Combustion, performance and emission characteristics of an unmodified diesel engine fueled with Manilkara Zapota Methyl Ester and its diesel blends," Applied Thermal Engineering, vol. 139, pp. 196-202, 2018.

[6] D. H. Qi, H. Chen, L. M. Geng, and Y. Z. Bian, "Experimental studies on the combustion characteristics and performance of a direct injection engine fueled with biodiesel/diesel blends," Energy Conversion and Management, vol. 51, pp. 2985-2992, 2010.

[7] A. Uyumaz, "Combustion, performance and emission characteristics of a DI diesel engine fueled with mustard oil biodiesel fuel blends at different engine loads," Fuel, vol. 212, pp. 256-267, 2018.

[8] M. M. Musthafa, T. A. Kumar, T. Mohanraj, and R. Chandramouli, "A comparative study on performance, combustion and emission characteristics of diesel engine fuelled by biodiesel blends with and without an additive," Fuel, vol. 225, pp. 343-348, 2018.

[9] E. Rama Krishna Reddy and V. Dhana Raju, "Experimental studies on natural aspirated diesel engine fuelled with corn seed oil methyl ester as a bio-diesel," IOP Conference Series: Materials Science and Engineering, vol. 330, p. 012104, 2018.

[10] S. Simsek and S. Uslu, "Determination of a diesel engine operating parameters powered with canola, safflower and waste vegetable oil based biodiesel combination using response surface methodology (RSM)," Fuel, vol. 270, p. 117496, 2020.

[11] M. R. Seraç, S. Aydın, A. Yılmaz, and S. Şevik, "Evaluation of comparative combustion, performance, and emission of soybean-based alternative biodiesel fuel blends in a CI engine," Renewable Energy, vol. 148, pp. 1065-1073, 2020. 
[12] M. Mohamed, C.-K. Tan, A. Fouda, M. S. Gad, O. Abu-Elyazeed, and A.-F. Hashem, "Diesel engine performance, emissions and combustion characteristics of biodiesel and its blends derived from catalytic pyrolysis of waste cooking Oil," Energies, vol. 13, 2020.

[13] S. Saraf and B. Thomas, "Influence of feedstock and process chemistry on biodiesel quality," Process Safety and Environmental Protection, vol. 85, pp. 360-364, 2007.

[14] J.-S. Lee and S. Saka, "Biodiesel production by heterogeneous catalysts and supercritical technologies," Bioresource Technology, vol. 101, pp. 7191-7200, 2010.

[15] I. A. Musa, "The effects of alcohol to oil molar ratios and the type of alcohol on biodiesel production using transesterification process," Egyptian Journal of Petroleum, vol. 25, pp. 21-31, 2016.

[16] R. Gangadhara and N. Prasad, "Studies on optimization of transesterification of certain oils to produce biodiesel," Chem. Int, vol. 2, p. 59, 2016.

[17] S. R. Kalbande and S. D. Vikhe, "Jatropha and Karanj bio-fuel: an alternate fuel for diesel engine," ARPN J Eng Appl Sci, vol. 3, pp. 7-13, 2008.

[18] K. Sivaramakrishnan and P. Ravikumar, "Determination of cetane number of biodiesel and its influence on physical properties," ARPN Journal of engineering and Applied Sciences, vol. 7, pp. 205-211, 2012.

[19] M. Chhabra, A. Sharma, and G. Dwivedi, "Performance evaluation of diesel engine using rice bran biodiesel," Egyptian Journal of Petroleum, vol. 26, pp. 511-518, 2017. 